\title{
Catheter Directed Thrombolysis Terapi Emboli Paru pada Ibu Hamil
}

\author{
Aulia Dita Maurizka \\ Fakultas Kedokteran Universitas Lampung \\ Email: auliaditamaurizka97@yahoo.com
}

\begin{tabular}{|c|c|}
\hline ARTICLE INFO & B STRACT \\
\hline $\begin{array}{l}\text { *) corresponding author } \\
\text { Fakultas Kedokteran Universitas Lampung1 } \\
\text { J1.Prof. Dr. Ir. Sumantri Brojonegoro No. 1, } \\
\text { Gedong Meneng, Kec. Rajabasa, Kota } \\
\text { Bandarlampung, Lampung } \\
\text { Telp. } 082281187338\end{array}$ & $\begin{array}{l}\text { The incidence of pulmonary embolism in developing countries is } \\
\text { increasing every day. Pulmonary embolism is a life-threatening } \\
\text { emergency. The incidence of pulmonary embolism is related to } \\
\text { physiological conditions of pregnant women where there is an increase } \\
\text { in coagulation factors such as factors I, II, VII, VIII, IX, X, increase in } \\
\text { fibrin and protein S. This causes pregnant women to be more } \\
\text { susceptible to stasis venous thromboembolism become Deep Vein } \\
\text { Thrombosis and if it continues to become a life-threatening pulmonary } \\
\text { embolism. Therapy in pulmonary embolism is still emphasized by the } \\
\text { use of thrombolytics to destroy the thrombus. However, based on } \\
\text { research in the last few years, it was found that serious complications } \\
\text { due to the use of thrombolytics such as bleeding, abortion, and even } \\
\text { maternal death. Therefore a new method was formed in the form of a } \\
\text { Catheter Directed Thrombolysis (CDT), which was able to reduce the } \\
\text { risk of bleeding in pregnant women with pulmonary embolism so that } \\
\text { they could get good results. CDT is a minimal intervention therapy by } \\
\text { inserting a catheter into the body until it approaches the thrombus in } \\
\text { the lungs, then removing thrombolysis agents around the thrombus in } \\
\text { the hope of thrombus lysis and not occurring hemodynamic disorders. }\end{array}$ \\
\hline
\end{tabular}

This is an open access article under the CC-BY-SA license.

\section{PENDAHULUAN}

Tromboemboli vena termasuk Deep Vein Thrombosis (DVT) dan Emboli Paru merupakan kejadian yang serius pada ibu hamil (Meng K, et al., 2015). Emboli paru merupakan penyebab salah satu penyebab utama angka kematian yang tinggi di negara maju. Angka kejadian tromboemboli vena meningkat mecapai 30\% saat menjelang persalinan pada 10.000 angka kelahiran (Lee MY, et al., 2014). Pada wanita hamil terjadi kenaikan angka resiko menjadi 4 sampai 5 kali untuk terkena emboli paru. Usia kehamilan sekitar 20 minggu, angka kejadian DVT meningkat hingga 75-80\% dan 20-25\% diantara berlanjut menjadi emboli paru (Simcox LE, et al., 2015). 
Peningkatan resiko ini menunjukkan hal yang sesuai dengan fisiologis pada kehamilan, yaitu darah mejadi lebih hiperkoagulabel yang dimulai pada tingkat konsepsi hingga 8 minggu pasca persalinan. Selain itu terjadinya peningkatan stasis vena di pelvis dan ekstremitas bawah akibat efek vasodilatasi dari hormon selama kehamilan dan obstruksi dari uterus juga menjadi salah satu faktor untuk terjadinya tromboemboli (Meng K, et al., 2015). Hal ini sesuai dengan kriteria Virchow yang mendeskripsikan mengenai tiga komponen tombosis yaitu hiperkoagulasi, stasis vena dan kerusakan endothelial pembuluh darah yang terjadi selama masa kehamilan dan persalinan (Simcox LE, et al., 2015).

\section{DIAGNOSIS EMBOLI PARU}

Tanda dan gejala VTE akut seperti pembengkakan kaki dan dyspnoea pada kehamilan sulit dibedakan dari gejala fisiologis normal kehamilan. Secara umum, wanita hamil yang datang dengan tanda-tanda dan gejala DVT akut seperti pembengkakan atau nyeri tungkai unilateral dan / atau nyeri perut yang merefleksikan perluasan ke pembuluh pelvis, harus menjalani tes dan pengobatan. Jika tidak diobati, DVT berkembang menjadi tromboemboli paru pada $15-24 \%$ pasien dan berpotensi fatal pada 15-30\% pasien (Simcox LE, et al., 2015).

Dalam membuat diagnosis embolii paru akut pada kehamilan, data laboratorium dan radiologi harus dipertimbangkan. Data laboratorium menunjukkan hipoksia dan peningkatan D-dimer, troponin-I (tingkat cedera jantung), dan NT-pro BNP (biomarker gagal jantung). Namun, batas D-dimer tidak jelas pada kehamilan karena konsentrasi D-dimer pada kehamilan lebih tinggi dari ambang biasa $(500 \mathrm{ng} / \mathrm{mL})$. Metode radiologii termasuk echografi jantung, pulmonary angiography dan ct scan thorax. Namun, harus dipertimbangkan untuk menghindari paparan radiasi pada bayi. Sebelum pemeriksaan CT scan echografi jantung adalah pemeriksaan rekomendasi pertama. Perkiraan radiasi yang diserap oleh janin selama CT dada sekitar 0,03 hingga 0,13 mSV, sama dengan 2 hingga 13 rontgen thorax. Angiografi pulmo 2,2 hingga 3,7 mSV, sama dengan 220 hingga 370 rontgen thorax (Yang YP et al., 2014).

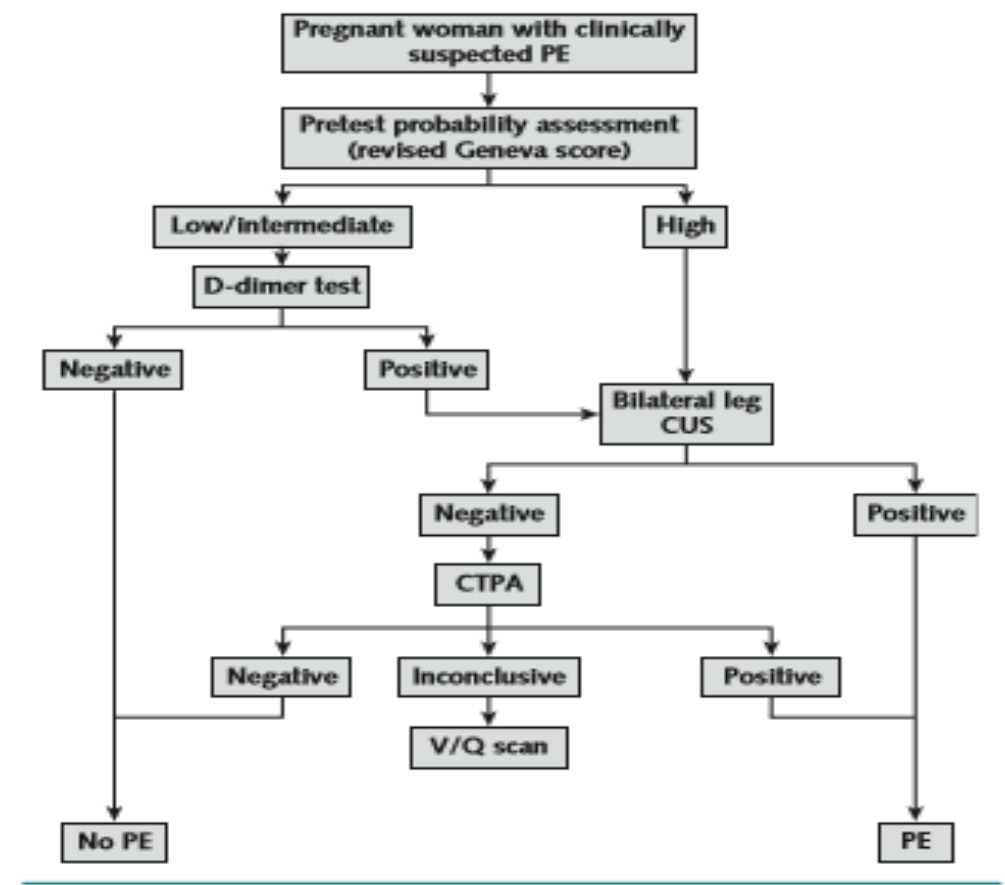

CTPA - computed tomography pulmonary angiography: CUS - compression ultrasonography: PE = pulmonary embolism; V/Q = ventilation-perfusion.

Gambar 2. Algoritma diagnosis tromboemboli paru ${ }^{7}$ 


\section{MEKANISME TERJADINYA EMBOLI PARU PADA KEHAMILAN}

Kehamilan normal menginduksi keadaan hiperkoagulasi. Keadaan ini merupakan hal multifaktorial yang terjadi akibat kontribusi dari perubahan fisik, hormonal dan hematologi. Perubahan fisik dan hormonal kehamilan dimulai pada awal trimester pertama. Peningkatan ini dimediasi oleh hormon progesteron yang menyebabkan terjadinya peningkatan dilatasi dan kapasitas vena. Hal ini mengakibatkan peningkatan stasis vena. DVT pada kehamilan di banyak kasus terjadi pada sisi sebelah kiri, hal ini mungkin berkaitan dengan peningkatan stasis vena di sebelah kiri. Kemudian secara anatomis pada ibu hamil terjadinya penekanan arteri iliaka sinistra oleh arteri iliaka dekstra dan penekanan ateri iliaka komunis karena terdapatnya pembesaran uterus (Stone SE, et al., 2015).

Perubahan hematologi pada kehamilan juga penting dalam patofisiologi tromboemboli vena termasuk peningkatan faktor pembekuan serta perubahan dalam pembentukan fibrin dan fibrinolisis. Peningkatan sirkulasi dari beberapa faktor pembekuan, termasuk faktor I, II, VII,VIII, IX, dan X, telah terbukti meningkat pada kehamilan dan masa nifas. Kadar protein $S$ baik yang terikat protein dan bebas, telah terbukti menurun dengan meningkatnya kehamilan. Aktivasi trombosit meningkat, sebagai respon fase akut. Fibrin juga meningkat terutama di trimester ketiga dan aktivitas fibrinolitik menurun. Kombinasi dari faktor-faktor ini menghasilkan keadaan hiperkoagulabel (Stone SE, et al., 2015).

Keadaan hiperkoagulasi ini sebenarnya merupakan hal yang normal terjadi selama masa kehamilan. Hal ini merupakan respon fisiologis tubuh dimana untuk mempersiapkan dan melindungi ibu pada saat terjadinya abortus dan melahirkan. Sehingga resiko terjadinya perdarahan akan sangat kecil. Namun di satu sisi hal ini juga dapat meningkatkan kejadian terjadinya trombomboli vena (Conti L, et al,. 2013).

Pada beberapa keadaan thrombus yang sudah terbentuk sebelumnya pada vena ekstremitas bawah dapat terlepas dan masuk ke vena cava inferior, atrium kanan, ventrikel kanan kemudian masuk ke paru-paru. Hal ini merupakan keadaan gawat darurat yang mengancam nyawa.

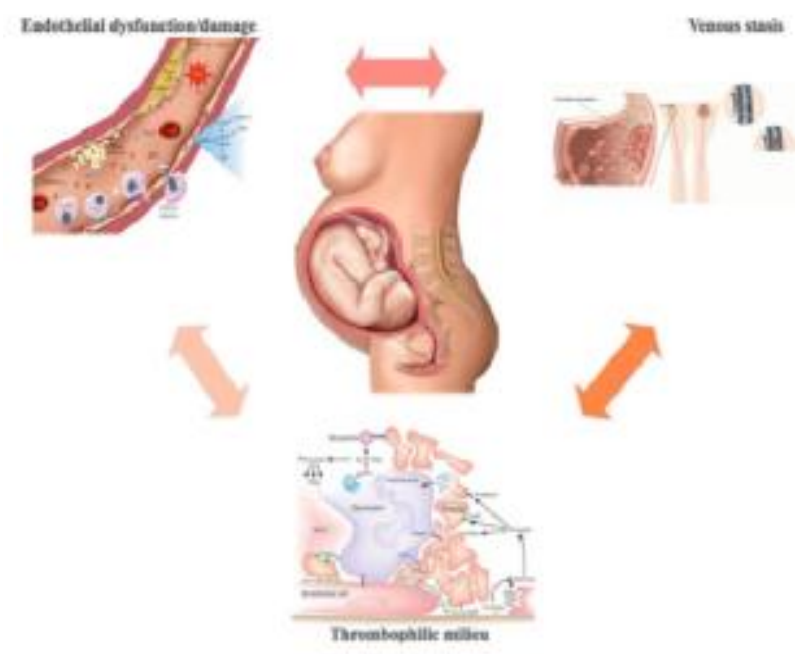

Gambar 1. Trias Virchow pada kehamilan ${ }^{5}$

\section{TATALAKSANA EMBOLI PARU}

Tatalaksana emboli paru pada kehamilan pasien masih belum jelas. Trombolitik dianggap sebagai standar lini pertama pengobatan pada pasien tidak hamil dengan VTE (Vena Trombo Emboli), namun pada kehamilan didapatkan beberapa komplikasi. Trombolisis dengan penggunaan streptokinase dan rekombinasi aktivator plasminogen (rt-PA), masih lebih dipakai karena injeksi 
heparin dapat menyebabkan fragmentasi yang lebih cepat pada emboli jika diberikan di dalam 24 jam pertama (Beebeejaun MY, et al., 2013).

Namun pemberian agen trombolitik ini mempunyai kompliasi yang cukup besar dalam kesejahteraan ibu dan janin (Gomes SM, et al., 2018). Komplikasi besar terkait dengan trombolisis termasuk abortus $(5,8 \%)$, kelahiran prematur $(5,8 \%)$, dan komplikasi perdarahan $(8,1 \%)$ (Beebeejaun MY, et al., 2013).

Laporan lain menyebutkan bahwa dengan total populasi kasus 25 wanita. Pada 17 kasus menggunakan agen spesifik fibrinolitik dan 8 kasus lainnya menggunakan streptokinase yang merupakan agen fibrinolitik non spesifik. Terdapat tiga kasus komplikasi perdarahan mayor, dua di antaranya dengan penggunaan SK dan satu dengan penggunaan reteplase. Dua kasus perdarahan sedang, satu menggunakan SK dan satu dengan rtPA; satu kematian ibu (paru postpartum emboli); satu kematian janin (sebelum penggunaan trombolitik); satu aborsi spontan dan satu kematian bayi baru lahir (RDS setelah 14 hari) (Gomes SM, et al.,2018).

Pilihan pengobatan untuk pasien yang tidak hamil dengan emboli paru berat dan hemodinamik tidak stabil adalah trombolitik, embolektomi secara pembedahan dan kateter embolektomi trombolisis. Te Raa et al. meninjau delapan kasus yang menjalani embolektomi bedah pada kehamilan, didapatkan hasil berupa tidak adanya angka kematian ibu, tiga kematian janin, dan empat kelahiran prematur dilaporkan. Hal ini menunjukkan bahwa kelangsungan hidup ibu dari embolektomi bedah tampaknya dapat diterima pada kehamilan, walaupun tingkat kematian janin sangat besar. Pada kehamilan, beberapa pedoman merekomendasikan bahwa trombolisis harus menjadi pilihan emboli paru berat. Dalam ulasan ini, ada tiga kasus perdarahan mayor, satu kematian ibu karena episode berulang emboli paru postpartum dan satu janin kematian sebelum terapi trombolitik (Gomes SM, et al.,2018).

Berdasarkan ulasan diatas dapat kita ketahui bahwa penggunaan trombolitik dapat menyebabkan berbagai komplikasi serius yang dapat mengancam nyawa ibu dan atau bayi itu sendiri. Penggunaan pembedahan embolektomi paru dapat menjadi salah satu pilihan walaupun dapat terjadi komplikasi setelahnya. Oleh karena itu diteliti kembali bagaimana tatalaksana yang terbaik untuk keadaan emboli paru pada ibu hamil agar keluaran yang dihasilkan dapat menyelamatkan ibu dan bayi.

Pilihan terapi lain yang dapat digunakan adalah dengan penggunaan kateter embolektomi trombolisis atau bisa disebut dengan Catheter Directed Thrombolysis (Gomes SM, et al.,2018). Saat ini CDT untuk manajemen emboli paru disarankan untuk emboli paru kelas IIa dan level B menurut ACC / AHA, yaitu emboli paru yang disertai kolaps kardiopulmoner atau hipotensi yang mengganggu hemodinamik. CDT memiliki keuntungan yang cukup besar dibandingkan terapi trombolitik sistemik karena memiliki risiko perdarahan yang rendah (Bloome TL, et al., 2017).

Meskipun trombolisis diberikan secara lokal selama CDT untuk PE, trombolisis dapat tersebar secara sistemik. Penyebaran sistemik terapi trombolitik adalah penyebab banyak komplikasi CDT yang parah. Oleh karena itu kontraindikasi terhadap CDT adalah riwayat stroke iskemik, perdarahan serebral, massa serebral, deformasi vaskular, ulkus baru di saluran pencernaan, operasi otak / tulang belakang, operasi laparatomi atau panggul dan adanya sumber perdarahan aktif apa pun. (Bloome TL, et al., 2017). Pada pasien yang kontraindikasi terhadap CDT pada kebanyakan kasus juga kontraindikasi terhadap fibrinolotik sistemik. Oleh karena itu pasien-pasien tersebut dirawat dengan terapi antikoagulan, antiplatelet atau perawatan suportif (Furfaro D, et al., 2017).

Prosedur CDT dimulai dengan mendapatkan akses vaskular dengan memasukkan jarum ke dalam sistem vena yang sudah dipilih. Kemudian satu benang menuntun guide wire melalui jarum dan naik melalui jantung kanan ke sistem paru yang dekat dengan trombus. Dengan menggunakan petunjuk fluoroskopi, kateter infus dilewatkan melalui guide wire dan melintasi lokasi trombus. 
Setelah diposisikan dengan benar, lepaskan guide wire. Masukkan ultrasonic core secara perlahan ke dalam kateter sampai ke posisi yang benar dan trombolisis dapat diberikan. Trombolisis keluar dari kateter melalui lubang samping sementara normal saline keluar melalui ujung distal. Ketika terapi selesai, lepaskan ultrasonic core dan ganti guide wire di dalam kateter. Selanjutnya, lepaskan kateter meninggalkan guide wire di tempatnya. Terakhir, lepaskan guide wire dan terapkan perangkat kompresi ke situs akses (Furfaro D, et al., 2017).

CDT adalah prosedur minor, tetapi seperti semua prosedur lainnya, namun dapat juga meninmbulkan komplikasi jika tidak dilakukan dengan benar. Namun jika pelaksanaannya secara benar dapat meningkatkan angka keberhasilan tatalaksana pada emboli paru ibu hamil dan dapat meningkatkan kesejahteraan ibu dan janin (Beebeejaun MY, et al., 2013).

Apabila dibandingkan dengan penggunaan trombolitik secara sistemik maka penggunaan CDT ini dapat lebih bermanfaat dalam hal untuk mengurangii resiko perdarahan bagi ibu hamil (Furfaro D, et al., 2017).

\section{METODE}

Suatu tinjauan literatur (literatur review) terhadap teori-teori yang relevan. Sumber tinjauan meliputi studi pencarian sistematis database (NCBI, Google scholar) yang berjumlah 11 jurnal.

\section{HASIL DAN PEMBAHASAN}

Kehamilan normal menginduksi keadaan hiperkoagulasi. Keadaan ini merupakan hal multifaktorial yang terjadi akibat kontribusi dari perubahan fisik, hormonal dan hematologi. Hal ini mengakibatkan peningkatan stasis vena. DVT pada kehamilan di banyak kasus terjadi pada sisi sebelah kiri, hal ini mungkin berkaitan dengan peningkatan stasis vena di sebelah kiri. Kemudian secara anatomis pada ibu hamil terjadinya penekanan arteri iliaka sinistra oleh arteri iliaka dekstra dan penekanan ateri iliaka komunis karena terdapatnya pembesaran uterus (Stone SE, et al., 2015).

Perubahan hematologi pada kehamilan juga penting dalam patofisiologi tromboemboli vena termasuk peningkatan faktor pembekuan serta perubahan dalam pembentukan fibrin dan fibrinolisis. Kadar protein $\mathrm{S}$ baik yang terikat protein dan bebas, telah terbukti menurun dengan meningkatnya kehamilan. Aktivasi trombosit meningkat, sebagai respon fase akut. Fibrin juga meningkat terutama di trimester ketiga dan aktivitas fibrinolitik menurun. Kombinasi dari faktorfaktor ini menghasilkan keadaan hiperkoagulabel (Stone SE, et al., 2015).

Keadaan hiperkoagulasi ini sebenarnya merupakan hal yang normal terjadi selama masa kehamilan. Hal ini merupakan respon fisiologis tubuh dimana untuk mempersiapkan dan melindungi ibu pada saat terjadinya abortus dan melahirkan. Sehingga resiko terjadinya perdarahan akan sangat kecil. Namun di satu sisi hal ini juga dapat meningkatkan kejadian terjadinya trombomboli vena (Conti L, et al,. 2013).

Pada beberapa keadaan thrombus yang sudah terbentuk sebelumnya, vena ekstremitas bawah dapat terlepas dan masuk ke vena cava inferior, atrium kanan, ventrikel kanan kemudian masuk ke paruparu sehingga dapat mengancam nyawa. Untuk menindak lajuti kejadian ini maka perlu tatalaksana yang sesuai.

Tatalaksana emboli paru pada kehamilan pasien masih belum jelas, namun trombolitik dianggap sebagai standar lini pertama pengobatan pada pasien tidak hamil dengan VTE (Vena Trombo Emboli), tetapi pada kehamilan didapatkan beberapa komplikasi. Trombolisis dengan penggunaan streptokinase dan rekombinasi aktivator plasminogen (rt-PA), masih lebih dipakai karena injeksi 
heparin dapat menyebabkan fragmentasi yang lebih cepat pada emboli jika diberikan di dalam 24 jam pertama (Beebeejaun MY, et al., 2013).

\begin{tabular}{lcc}
\hline & Manifestasi & N\% \\
\hline Dyspnea & $11(84.6)$ \\
Chest pain & $4(30.8)$ \\
Cardiac arrest & $1(7.7)$ \\
Syncope & $1(7.7)$ \\
Seizure & 0 \\
Cough & 0 \\
Hemoptysis & 0 \\
\hline
\end{tabular}

Gejala yang paling umum dari pasien PAPE adalah dispnea (11kasus, 84,6\%) atau nyeri dada (4 kasus, 30,8\%). Gagal jantung dan sinkop masing-masing terdeteksi dalam satu kasus. Manifestasi termasuk kejang, batuk, dan hemoptisis tidak terdeteksi dalam kasus PAPE. Hasil rontgen dada saat itu manifestasi adalah sebagai berikut: normal pada 10 dari 13 kasus $(76,9 \%)$, efusi pleura pada 1 $(7,7 \%)$, edema paru pada $1(7,7 \%)$, dan kardiomegali pada $1(7,7 \%)$. Elektrokardiogram abnormal pada 4 dari 13 pasien $(30,8 \%)$; dua pasien takikardia $(15,4 \%)$, satu pasien memiliki kelainan ST-T $(7,7 \%)$, dan 1 pasien mengalami deviasi aksis kanan $(7,7 \%)$.

\section{SIMPULAN DAN SARAN}

Kejadian Emboli Paru merupakan kejadian mengancam nyawa yang meningkat kejadiannya pada ibu hamil. Hal ini dikarenakan kondisi fisiologis ibu hamil yang terjadi peingkatan faktor-faktor koagulasi darah yang dipersiapkan untuk proses kelahiran agar tidak terjadinya perdarahan. Pada lain sisi kejadian ini dapat menimbulkan kondisi pembentukan thrombus yang dapat mengendap di ekstremitas bahkan hingga sampai ke paru. Terapi yang selama ini digunakan untuk mengatasi emboli paru pada ibu hamil ini adalah dengan agen trombolitik. Namun penggunaan agen ini ternyata berdampak tinggi terhadap terjadinya perdarahan yang dapat menyebabkan kematian ibu dan janin. Oleh karena itu para peneliti melakukan percobaan terapi terbaru untuk meningkatkn hasil keberhasilan terapi pada emboli paru ibu hamil dengan menggunakan Catheter Directed Thrombolysis. Proses ini dapat lebih bermanfaat dan mempunyai resiko perdarahan yang lebih kecil sehingga dampak terhada ibu dan janin lebih sedikit.

\section{DAFTAR PUSTAKA}

Beebeejaun MY \& Adenugba O. (2013). Use of thrombolytic agents to treat pulmonary embolism in pregnancy. Rev Obstet Gynecol, 6(3/4), 182-4.

Conti L, Zezza E, Ralli C, Comito L, Sada J, Passerini D, et al. (2013). Pulmonary embolism in pregnancy. J Thromb Thrombolysis, 34(11), 1-21.

Furfaro D, Stephens RS, Streiff MB \& Brower R. (2017). Catheter-directed thrombolysis for intermediate-risk pulmonary embolism. ANNALSATS, 40(10), 1-32.

Gomes SM, Guimarães M \& Nuno M. (2018). Thrombolysis in pregnancy: a literature review. The Journal of Maternal-Fetal \& Neonatal Medicine 20 (10), 1-25. 
Lee MY, Kim MY, Han JY, Park JB, Lee K \& Ryu HM. (2014). Pregnancy-associated pulmonary embolism during the peripartum period: an 8-year experience at a single centre. Obstet Gynecol Sci, 57(4), 260-65.

Meng K, Hu X, Peng X, \& Zhang Z. (2015). Incidence of venous thromboembolism during pregnancy and the puerperium: a systematic review and meta-analysis. Journal Of MaternalFetal \& Neonatal Medicine, 28(3), 245-53.

Righini M, Ebadi HL, Elias A, Sanchez O, Moigne EL, Schmidt J, et al. (2018). Diagnosis of Pulmonary Embolism During Pregnancy. Annals of Internal Medicine, 60(18), 1-9.

Simcox LE, Ormesher L, Tower C, et al. (2015). Pulmonary thromboembolism in pregnancy: diagnosis and management. Breathe, 11, 282-89.

Stone SE \& Morris TA. (2015). Pulmonary embolism during and after pregnancy. Crit Care Med, 33(10), 294-300.

TL, Haye GE, Daniel MC, Sandvall BC, Liberman HA, Devireddy CM, et al. (2017). Safety of catheter-directed thrombolysis for massive and submassive pulmonary embolism: results of a multicenter registry and meta-analysis. The Society for Cardiovascular Angiography and Interventions, 81(10), 1-8.

Yang YP \& Lin, LS. (2014). A pregnant woman with acute massive pulmonary embolism. Acta Cardiol Sin, 30, 82-5. 
Wellness and Healthy Magazine, 2(1), February 2020, - 48 Aulia Dita Maurizka 